\title{
ResearchArticle
}

\section{Study of different grains on spawn development of $P$. sajor caju (Fr.) Singer}

\author{
NAZIMA KHATOON AND PRASHANT SHARMA
}

\section{SUMMARY}

The important priority of profession is to maximize the production of mushroom by using various techniques. Mushroom seed (Spawn) production involves sophisticated technology with high investment requiring laboratory and equipments with accessories. The major constraint in mushroom production is non-availability of spawn. The technology of spawn production is given by Eco-care and Aware. We tested three grains viz., wheat, rice and gram for production of Pleurotus sajor caju spawn (Fr.) Singer. Plurotus sajor caju spawn has been recognized as a highly potential converter of cheap cellulosic material in to valuble protein at a very nominal cost. The results obtained during the present investigation are rice grains (9.00 days) were found to be the best grains for speedy development of spawn of Pleurotus sajor caju (Fr.) Singer.

Key Words : Pleurotus sajor caju, Different grains, Grain, Spawn

How to cite this article : Khatoon, Nazima and Sharma, Prashant (2017). Study of different grains on spawn development of P. sajor caju (Fr.) Singer. Internat. J. Plant Sci., 12 (2): 220-222, DOI: 10.15740/HAS/IJPS/12.2/220-222.

Article chronicle : Received : 15.04.2017; Revised : 23.05.2017; Accepted : 14.06.2017

\section{MEMBERS OF THE RESEARCH FORUM}

Author to be contacted :

PRASHANT SHARMA, Biotech Lab Training and Demonstration

Centre, AMBIKAPUR (C.G.) INDIA

Address of the Co-authors:

NAZIMA KHATOON, Biotech Lab Training and Demonstration Centre, AMBIKAPUR (C.G.) INDIA

Email : khan.nazi786@gmail.com 